\title{
SUPRESSION OF PODWERY MILDEW ON FLAX BY FOLIAR APPLICATION OF FUNGICIDES \\ Aly, A. A. ${ }^{1}$; M. R. Omar ${ }^{1}$ and M. M. M. Hussein ${ }^{2}$ \\ 1 Plant Pathology Res. Inst., Agric. Res. Center, Giza, Egypt. \\ ${ }^{2}$ Field Crops Res. Inst., Agric. Res. Center, Giza, Egypt.
}

\begin{abstract}
A two-year field study was conducted at El-Ismailiya Agricultural Research Station to evaluate the fungicides Bellis and Micronized Sulphur, applied as foliar sprays, for control of powdery mildew on six flax cultivars (Giza 9, Giza 10, Sakha 3, Sakha 4, Istro, and Jiteka) with varying levels of susceptibility to the disease. Disease severity, agronomic traits, and technological traits were used as criteria for evaluating the performance of the tested fungicides. Bellis and sulphur were effective in controlling the disease (reducing the disease severity) in 2011 and 2012 on all the tested cultivars; however, efficiency of the fungicides (magnitude of reduction in the disease severity) in controlling the disease differed from one cultivar to another and from year to year. Bellis did not contribute to significant increases in many agronomic and technological traits of the tested cultivars in 2011 and 2012, while sulphur significantly improved, with few exceptions, almost all the tested traits. In conclusion, the present study demonstrated that both Bellis and sulphur were effective in reducing the disease severity; however, sulphur surpassed Bellis in improving agronomic and technological traits. Therefore, sulphur is better choice than Bellis for controlling the disease.
\end{abstract}

Keywords: Flax (Linum usitatissimum L.) cultivars, powdery mildew (Oidium lini Skoric), fungicides, disease severity.

\section{INTRODUCTION}

Powdery mildew, caused by Oidium lini Škoric, is widely distributed and a destructive disease of flax (Linum usitatissimum L.) in Egypt. Flax is grown for both seeds and fibers in the Nile Delta, in particular, the northern governorates. This area is characterized by the prevalence of warm, wet weather during the late period of flax growing season. Such weather favors epiphytotic spread of the disease when virulent isolate of $O$. lini presents (Mansour, 1998). However, yield losses and disease intensity vary from year to year depending on location, fertilization, weather conditions, and cultivars (Mansour, 1998).

Currently, resistance to powdery mildew is not available in commercially grown flax cultivars in Egypt. Therefore, in years when environmental conditions favor the development of the disease, foliar application of fungicides has become the only commercially available management practice for the disease control. These fungicides include sulpher and sterol biosynthesis inhibitors, such as Bayleton, Bayfidan, and Rubigan (Khalil et al., 1987, Aly et al., 1994, Mansour, 1998, Mansour et al., 1999, and Aly et al., 2000).

The objective of this study was to evaluate the effects of foliar fungicides on the development of powdery mildew epidemics and on agronomic and 
Aly, A. A. et al.

technological traits of flax cultivars with varying levels of susceptibility to $O$. lini.

\section{MATERIALS AND METHODS}

Experiments were conducted over two successive growing seasons at ElIsmailiya Agricultural Research Station, beginning in the fall of 2010. Experiments consisted of a randomized complete block design of four replications (blocks). Plots were $2 \times 3 \mathrm{~m}\left(6 \mathrm{~m}^{2}\right)$ and consisted of 20 rows spaced $10 \mathrm{~cm}$ apart. Plots were manually planted with the tested cultivars (Table 1) at a rate of $50 \mathrm{~kg} / \mathrm{feddan}$ on 20 November 2010 and on 25 November 2011. All the agricultural practices for growing flax were conducted according to the recommendations. Powdery mildew was allowed to develop naturally, and the initial fungicide application to cultivars coincided with the first sign of the disease. Foliar sprays were applied at the recommended rates (Table 2) on 10 and 24 April 2011 and on 25 April and 10 May 2012. Disease severity (Nutter et al., 1991) was rated visually on 10 May 2011 and on 25 May 2012. Disease severity was measured as percentage of infected leaves/plant in a random sample of 10 plants/plot. Fungicidal efficiency was calculated based on disease severity according to the following formula [(DSC-DSF)/DSC] $\times 100$, where DSC is disease severity of the control (untreated plots) and DSF is disease severity of fungicide-treated plots.

Table (1). Origin, type, and pedigree of flax cultivars used in the present study.

\begin{tabular}{|c|l|l|l|l|}
\hline No. & \multicolumn{1}{|c|}{ Cultivar } & \multicolumn{1}{|c|}{ Origin } & \multicolumn{1}{c|}{ Type } & \multicolumn{1}{c|}{ Pedigree } \\
\hline 1 & Giza 9 & Local cultivar & Fiber & L. 420 x Bombay \\
\hline 2 & Giza 10 & Local cultivar & Fiber & L. 420 x Bombay \\
\hline 3 & Sakha 3 & Local cultivar & Fiber & Bleinka (2E) x 1.2096 \\
\hline 4 & Sakha 4 & Local cultivar & Fiber & Bleinka (R3) x 1.2096 \\
\hline 5 & Istro & $\begin{array}{l}\text { Introduced } \\
\text { Romania }\end{array}$ & Fiber & Unidentified \\
\hline 6 & Jiteka & Introduced from Czech & Fiber & Unidentified \\
\hline
\end{tabular}

Table (2).Fungicides used for control of powdery mildew of flax under field conditions in El-Ismailiya in 2010/2011 and 2011/2012 growing seasons.

\begin{tabular}{|l|c|l|l|}
\hline \multicolumn{1}{|c|}{ Fungicides $^{\mathbf{a}}$} & $\begin{array}{c}\text { Rate (per 100 } \\
\text { liters of water) }\end{array}$ & \multicolumn{1}{|c|}{ Active ingredient $^{\mathbf{b}}$} & \multicolumn{1}{c|}{ Formulation $^{25 \% \mathrm{w} / \mathrm{w} \text { boscalid (protectant) }+}$} \\
\hline Bellis & $50 \mathrm{ml}$ & $\begin{array}{l}25.2 \% \text { water dispersible } \\
12.8 \% \mathrm{w} / \mathrm{w} \text { pyraclostrobin } \\
\text { (systemic) }\end{array}$ & $\begin{array}{l}\text { A wranules } \\
\text { gram }\end{array}$ \\
\hline Micronized Sulphur & $250 \mathrm{~g}$ & $80 \%$ Micronized Sulphur & Wettable granules \\
\hline
\end{tabular}

a Trade name

${ }^{b}$ Common name

At harvest, a random sample of 10 plants was taken from each plot and observations were recorded on individual plants for each of the following agronomic and technological traits: 
A. Straw yield and its related characters:

1. Total plant height $(\mathbf{c m})$ : Plant height from the cotyledonary node to the apical bud of each plant.

2. Technical stem length $(\mathbf{c m})$ : The length of the main stem from the cotyledonary node to the first or lowest branching point.

3. Straw yield/plant (g): Weight of the mature air-dried straw per plant after removing the capsules.

4. Straw yield/feddan (ton): Estimated based on the area of the whole plot.

5. Fiber yield/feddan (ton): Estimated based on the area of the whole plot after retting.

B. Seed yield and its related characters:

1. Number of apical branches: Total number of apical branches of plant.

2. Number of capsules per plant: Number of harvested capsules per plant.

3. Number of seeds per capsules: Number of harvested seeds per capsule.

4. Seed index (g): Weight of 1000 seeds.

5. Seed yield/plant (g): Weight of harvested seeds per plant.

6. Seed yield/feddan (kg): Estimated based on the area of the whole plot.

C. Technological traits:

1. Fiber length (cm): Estimated as the mean of 10 fiber ribbons (bundles) from each plot.

2. Long fiber percentage: Calculated according to the following formula:

$$
\text { Long fiber }(\%)=\frac{\text { Long fiber yield/fed }}{- \text { Straw yield/fed }^{\prime}} \times 100
$$

3. Fiber fineness in metrical number $(\mathbf{n m})$ : Calculated according to the following formula:

Fiber fineness $(\mathrm{nm})=\stackrel{\mathrm{N} \times \mathrm{L}}{--------} \quad$ (Radwan and Momtaz, 1966)

$$
\text { G }
$$

Where $\quad \mathrm{N}=$ Number of fibers (20 fibers)

$\mathrm{L}=$ Length of fibers in $\mathrm{cm}$.

$\mathrm{G}=$ Weight of fibers in $\mathrm{mg}$.

4. Oil percentage: Determined by Soxhlet apparatus according to Horwitz et al. (1965).

5. Oil yield/fed. (kg): Oil (\%) x seed yield/fed. $(\mathrm{kg})$.

Statistical analysis of the data:

Analysis of variance (ANOVA) was performed on disease severity, agronomic traits, and technological traits to determine treatment effects. Mean comparisons for variables were made among treatments by Duncan's multiple range test. ANOVA was performed with the MSTAT-C Statistical Package. 
Aly, A. A. et al.

\section{RESULTS AND DISCUSSION}

The fungicides used to control powdery mildew vary in modes of action. The protective fungicides (e.g., sulphur and Boscalid) are surface protectants that suppress fungal growth and sporulation either by direct contact or vapor phase activity. Most of the systemic fungicides (e.g., pyraclostrobin) inhibit hyphal and haustarial growth and sporulation, and some also exhibited vapor phase activity (Seem et al., 1981). The use of fungicides for control of powdery mildews caused by Oidium spp. is well documented in the literature (Strider, 1980, Quinn and Powell, 1982, Ranson et al., 1991, and Lonsdale and Kotze, 1993).

In Egypt, control of flax powdery mildew (FPM) caused by Oidium lini under greenhouse and field conditions (Khalil et al., 1987, Aly et al., 1994, Mansour, 1998, Mansour et al., 1999, and Aly et al., 2000) in the form of foliar sprays has been shown to suppress the disease. However, field evaluation of the effect of flax genotype on the efficiency of fungicides has not been previously determined. Therefore, the present study was conducted in the 2010/2011 and 2011/2012 growing seasons (hereafter referred to as years 2011 and 2012, respectively) to explore the possible effects of six flax cultivars, with varying levels of susceptibility to powdery mildew, on efficiency of fungicides in controlling the disease under field conditions. Disease severity, agronomic traits (yield and yield components), and technological traits were used as criteria for evaluation of the tested fungicides.

Based on disease severity on the tested cultivars in the control treatments, which did not receive fungicides, it was possible to classify the cultivars in 2011 into highly susceptible (Istro and Jiteka), susceptible (Giza 9 and Sakha 4), moderately susceptible (Giza 10), and moderately resistant (Sakha 3). In 2012, they could be classified into highly susceptible (Giza 9 and Sakha 3, Sakha 4, and Jiteka), susceptible (Istro), and moderately susceptible (Giza 10). In general, the mean disease severity in the control treatments of the tested cultivars was $82.39 \%$ in 2011 and $93.63 \%$ in 2012 . The number of the highly susceptible cultivars (100\% disease severity) increased from two in 2011 to four in 2012. These results indicate that environmental conditions of 2012 were more favorable for the occurrence of FPM than those of 2011. The results also indicate that the fungicides were tested, for efficiency in controlling FPM under high disease pressure in both years. This high disease pressure is considered a prerequisite condition for any meaningful field evaluation of fungicides. The differences in disease severity among some cultivars in the control treatments varied from one year to another. For example, the difference between Sakha 3 and Sakha 4 was significant in 2011, while it was nonsignificant in 2012. Another example is the difference between Istro and Jiteka was nonsignificant in 2011 and significant in 2012. These results may indicate the occurrence of cultivar $x$ year (environment) interaction.

Giza 10 showed the most stable disease reaction because it was moderately susceptible in both years. On the other hand, Sakha 3 showed unstable disease reaction because it was moderately susceptible in 2011 and highly susceptible in 2012. 
Bellis and sulphur were effective in controlling the disease (reducing the disease severity) in 2011 and 2012 on all the tested cultivars (Tables 3 and 4). In 2011, Bellis was more efficient than sulphur in controlling the disease on Giza 9, Sakha 3, Sakha 4 and Istro. On the other hand, sulphur was more effective on Giza 10 and Jiteka (Table 3). In 2012, Bellis was more effective on Giza 10, and Istro, while sulphur was more effective on Giza 9 and Jiteka. Bellis and sulphur were equally effective in controlling the disease on Sakha 3 and Sakha 4 (Table 4).

Efficiency of fungicides (magnitude of reduction in the disease severity) in controlling the disease differed from one cultivar to another. For example, in 2011, the efficiency of Bellis on controlling the disease on Giza $9(77.02 \%)$ was higher than its efficiency on Giza 10 (65.28\%). On the other hand, sulphur showed inverted performance in controlling the disease on the two cultivars. Thus, its efficiency on Giza 9 (49.99\%) was lower than its efficiency on Giza 10 (79.58\%), (Table 3).

Efficiency of fungicides also varied from year to year. For example, the efficiency of Bellis in controlling the disease on Giza 9 decreased from 77.02 in 2011 to 56.77 in 2012. On Giza 10, the efficiency of Bellis increased from 65.28 in 2011 to $76.60 \%$ in 2012 (Tables 3 and 4). Efficiency of sulphur in controlling the disease on Giza 9 increased from 49.99 in 2011 to $70.75 \%$ in 2012. On Giza 10, its efficiency decreased from 79.58 (in 2011) to $51.05 \%$ (in 2012) (Tables 3 and 4).

The effects of cultivar and year (environmental conditions) on efficiency of fungicides in controlling FPM, as we have demonstrated herein, have been previously reported by Aly et al. (2000). These results suggest that efficiency of fungicides in controlling FPM should be evaluated in as many years as possible by using as many cultivars as possible as this will improve the chance of identifying fungicides effective in controlling the disease on many cultivars under different environments.

Bellis did not contribute to significant increases in many agronomic and technological traits of the tested cultivars in 2011 and 2012 (Table 3 and 4). This ineffectiveness of Bellis in improving some agronomic traits could be attributed to interplot interference, which obscures the response of some agronomic traits to Bellis (Frank and Ayers, 1986, and Lipps and Madden, 1988). The experimental design of the present study was completely randomized blocks of four replications. In each block (replication), plots of the different treatments were adjacent to one another. Inoculum from heavily infected plants in the control plots would have had an effect on those in the other plots. The ultimate influence would be higher than normal levels of disease and lower agronomic traits responses in treated plots, thus leading to apparent loss of efficiency. In commercial-sized fields, foliar application of Bellis would be expected to control FPM and improve agronomic traits to a greater extent than observed in the present study (Lipps and Madden, 1988). 
Aly, A. A. et al.

3 
J. Plant Prot. and Path., Mansoura Univ., Vol. 4 (6), June, 2013

3 
Aly, A. A. et al.

4

598 
J. Plant Prot. and Path., Mansoura Univ., Vol. 4 (6), June, 2013

4 


\section{Aly, A. A. et al.}

Sulphur is a constituent of the amino acids cysteine and methionine. Cysteine is important in regulating the structure and function of protein. Sulphur is also a component of several coenzymes and plant hormones, a constituent of many active groups involved in oxidation-reduction reactions, and a component of sulfolipids, which are structural constituents of all biological membranes (Kirkpatrick and Rothrock, 2001). Therefore, it was not surprising to find significant increases in almost all the tested agronomic and technological traits, with few exceptions, by the foliar application of sulphur (Tables 3 and 4). Our results are in agreement with those of Chourasia et al. (1992), who reported beneficial effects of sulphur on growth, yield, and quality of linseed.

Both Bellis and sulphur were effective in reducing disease severity; however sulphur surpassed Bellis in improving the agronomic and the technological traits. These results suggest that sulphur is a better choice than Bellis for controlling the disease.

\section{REFERENCES}

Aly, A.A., A.Z.A. Ashour, E.A.F. El-Kady, and M.A. Mostafa. 1994. Effectiveness of fungicides for control of powdery mildew of flax and effect of the disease on yield and yield components. J. Agric. Sci. Mansoura Univ. 19:4383-4393.

Aly, A.A., M.T.M. Mansour, M.S.A. Felaifel, S.M.E. Zayed, and A.M. ElKafrawy. 2000. Use of fungicides, bicarbonate salts, and film-forming polymers to suppress powdery mildew of flax. J. Agric. Sci. Mansoura Univ. 25:6131-6151.

Chourasia, S.K., K.N. Namdeo, and C. Chaurasia. 1992. Effect of nitrogen, sulphur, and boron on growth, yield, and quality of linseed (Linum usitatissimum). Indian J. Agron. 37: 496-499.

Frank, J.A. and J.E. Ayers. 1986. Effect of Triadimenol seed treatment on powdery mildew epidemics on winter wheat. Phytopathology 76: 254257.

Horwitz, W., A.H. Robertson, E.A. Epps, F.W. Quackenush, and H. Reynolds. 1965. Official Methods of Analysis. Association of Official Agricultural Chemist, Washington.

Khalil, M.S., B.A. Youssef, H.A. Eisa, and Afaf M. Amr. 1987. Status of varietal reaction and chemical control of flax powdery mildew caused by Oidium lini. pp. 347-358. In: Proc. $5^{\text {th }}$ Congr. Egypt. Phytopathol. Soc., Giza.

Kirkpatrick, T.L. and C.S. Rothrock. eds. 2001. Compendium of Cotton Diseases. $2^{\text {nd }}$ Ed. The American Phytopathological Society. St. Paul., Minnesota. $77 \mathrm{p}$.

Lipps, P.E. and L.V. Madden. 1988. Effect of Triadimenol seed treatment and Triadimefon foliar treatment on powdery mildew epidemics and grain yield of winter wheat cultivars. Plant Dis. 72: 887-892.

Lonsdale, J.H. and J.M. Kotze. 1993. Chemical control of mango blossom diseases and the effect on fruit set and yield. Plant Dis. 77: 558-562. 
Mansour, M.T.M.1998. Pathological studies on powdery mildew of flax in A.R.E. Ph.D. Thesis, Zagazig Univ., Moshtohor, 148 p.

Mansour, M.T.M., A.A. Aly, S.M.E. Zayed, and M.A. Mostafa. 1999. Effectiveness of seed treatments and foliar fungicides for control of powdery mildew of flax cultivars. J. Agric. Sci. Mansoura Univ. 24:54975508.

Nutter, F.W., Jr. P.S. Teng, and F.M. Shoks. 1991. Disease assessment terms and concept. Plant Dis. 75: 1187-1188.

Quinn, J.A. and C.C. Powell, Jr. 1982. Effectiveness of new systemic fungicides for control of powdery mildew of begonia. Plant Dis. 66: 718720.

Radwan, S.R. and A. Momtaz. 1966. The technological properties of flax fiber and their estimation method (In Arabic). El-Felaha J. 46: 466-476.

Ranson, L.M., R.G. O'Brien, and R.J. Glass. 1991. Chemical control of powdery mildew in green peas. Australian Plant Pathology 20: 16-20.

Seem, R.C., J.D. Gilpatrick, and R.C. Pearson. 1981. Fungicide influence on the relationship between incidence and severity of powdery mildew on apple. Phytopathology 71: 947-950.

Strider, D.L. 1980. Resistance of African violet to powdery mildew and efficacy of fungicides for control of the disease. Plant Dis. 64: 188.190.

$$
\begin{aligned}
& \text { مكافــة البيـاض الـققيقى على الكتــان بـرش المطهرات الفطريـة على المجمـوع } \\
& \text { الخضى عبدالهادى على } 1 \text { ، معوض رجب عمر 1 1، مهذى محمد مهرى حسين } 2
\end{aligned}
$$

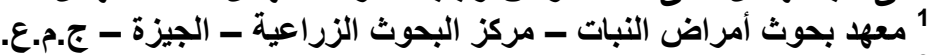

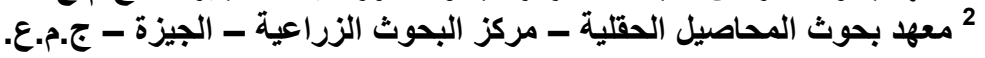
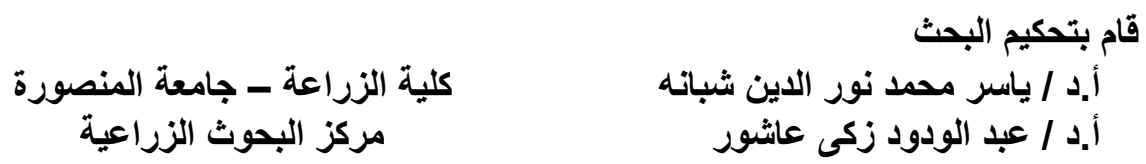
Aly, A. A. et al. 
Table (3). Effect of flax cultivars and fungicides on powdery mildew severity, agronomic, and technological traits under field conditions in 2010/2011 growing season.

\begin{tabular}{|c|c|c|c|c|c|c|c|c|c|c|c|}
\hline \multirow[b]{2}{*}{ No. } & \multicolumn{2}{|c|}{ Treatment } & \multirow[b]{2}{*}{$\begin{array}{c}\text { Disease } \\
\text { severity }(\%)^{d}\end{array}$} & \multicolumn{8}{|c|}{ Agronomic and technological traits } \\
\hline & Cultivar & Fungicide & & $\begin{array}{l}\text { Total plant } \\
\text { length (cm) }\end{array}$ & $\begin{array}{c}\text { Technical } \\
\text { plant length } \\
\text { (cm) }\end{array}$ & \begin{tabular}{|c|} 
Straw \\
yield/plant \\
(g)
\end{tabular} & $\begin{array}{c}\text { Straw } \\
\text { yield/fed. } \\
\text { (ton) }\end{array}$ & $\begin{array}{c}\text { Fiber } \\
\text { yield/fed } \\
\text { (ton) }\end{array}$ & $\begin{array}{l}\text { Long fiber } \\
\text { percentage }\end{array}$ & $\begin{array}{c}\text { Fiber } \\
\text { length }(\mathrm{cm})\end{array}$ & $\begin{array}{c}\text { Fiber } \\
\text { fineness } \\
(\mathrm{Nm})\end{array}$ \\
\hline 1 & Giza 9 & Control $^{a}$ & $87.83 \mathrm{~b}$ & $96.97 \mathrm{f}-\mathrm{I}$ & 86.77 def & 1.022 def & $3.684 \mathrm{cde}$ & $0.542 \mathrm{gh}$ & $14.73 \mathrm{e}$ & $85.64 \mathrm{fgh}$ & $237.7 \mathrm{bcd}$ \\
\hline 2 & Giza 9 & Bellis $^{b}$ & $20.18 \mathrm{~h}^{*}$ & $110.30 \mathrm{abc}^{*}$ & $98.05 \mathrm{abc}^{*}$ & $1.228 \mathrm{bc}^{*}$ & $4.421 \mathrm{~b}^{*}$ & $0.780 \mathrm{~cd}^{*}$ & $17.66 \mathrm{~b}^{*}$ & $102.70 a b^{*}$ & $281.0 a^{*}$ \\
\hline 3 & Giza 9 & Sulphur ${ }^{c}$ & & & $101.80 \mathrm{a}^{*}$ & $1.433 \mathrm{a}^{*}$ & $5.266 \mathrm{a}^{*}$ & $1.033 \mathrm{a}^{*}$ & & & $295.1 \mathrm{a}^{*}$ \\
\hline 4 & Giza 10 & & & & & 0.957 efg & & & & & $226.0 \mathrm{~cd}$ \\
\hline 5 & Giza 10 & Bellis & & & $b-e^{*}$ & $1.148 \mathrm{~b}-\mathrm{e}$ & $232 \mathrm{bc}^{*}$ & 0.686 def $^{*}$ & & & $269.0 \mathrm{abc}$ \\
\hline 6 & Giza 10 & Sulphur & & 107.0 & $94.83 a-d^{*}$ & $1.339 a^{*} b^{*}$ & $4.938 \mathrm{a}^{*}$ & $0.910 b^{*}$ & $4 b^{*}$ & $102.80 \mathrm{ab}^{*}$ & $290.6 a^{*}$ \\
\hline 7 & Sakha 3 & Control & & & & $0.836 \mathrm{f}-\mathrm{i}$ & & & & & $225.9 \mathrm{~cd}$ \\
\hline 8 & Sakha 3 & Bellis & & & & 1.002 def & 3.68 & & & & $266.9 \mathrm{abc}$ \\
\hline 9 & Sakha 3 & Sulphur & & & $5 a b^{*}$ & $1.169 \mathrm{bcd}^{*}$ & $4.391 \mathrm{~b}^{*}$ & $796 c^{\star}$ & $2 b^{*}$ & $\mathrm{bc}^{*}$ & $276.9 a b^{*}$ \\
\hline 10 & Sakha 4 & Control & & & & $0.739 \mathrm{hij}$ & & & & & $217.7 d$ \\
\hline 11 & Sakha 4 & Bellis & & & & & & & & 90. & $257.1 \mathrm{a}-\mathrm{d}$ \\
\hline 12 & Sakha 4 & Sulphur & & 106 & $a-d^{*}$ & $1.034 c-f^{*}$ & $4.369 \mathrm{~b}^{*}$ & $0.696 \mathrm{de}^{*}$ & & $7 \mathrm{~cd}^{*}$ & $268.8 a^{a b c} c^{*}$ \\
\hline 13 & Istro & Control & & $91.03 \mathrm{i}$ & $91 \mathrm{gh}$ & $0.661 \mathrm{ij}$ & $3.028 \mathrm{fg}$ & $0.346 \mathrm{kl}$ & $30 \mathrm{ij}$ & $74.72 \mathrm{jk}$ & $216.3 d$ \\
\hline 14 & Istro & Bellis & & & & $0.792 \mathrm{~g}-\mathrm{j}$ & $3.631 \mathrm{de}^{*}$ & & $5 \mathrm{fg}^{*}$ & & $243.4 \mathrm{bcd}$ \\
\hline 15 & Istro & & & & & $0.924 \mathrm{fgh}^{*}$ & $\mathrm{bcd}^{*}$ & efg $^{*}$ & $\mathrm{de}^{*}$ & $\mathrm{def}^{*}$ & $266.0 \mathrm{abc}^{\star}$ \\
\hline 16 & Jiteka & Control & & 441 & & $0.602 \mathrm{j}$ & 2.52 & 0.269 I & $10.74 \mathrm{j}$ & $70.64 \mathrm{k}$ & $215.2 d$ \\
\hline 17 & Jiteka & Bellis & $74.92 d^{*}$ & 95.2 & $84.37 \mathrm{efg}^{*}$ & 0.722 hij & $3.025 \mathrm{fg}$ & $0.391 \mathrm{jk}^{*}$ & $12.88 \mathrm{gh}^{*}$ & $84.34 \mathrm{ghi}^{*}$ & 240.0 bcd \\
\hline 18 & Jiteka & Sulphur & $50.33 \mathrm{e}^{\star}$ & $100.20 \mathrm{~d}-\mathrm{h}^{*}$ & $85.36 \mathrm{~d}-\mathrm{g}^{*}$ & $0.843 \mathrm{f}-\mathrm{i}^{*}$ & $3.867 \mathrm{bcd}^{*}$ & $0.552 \mathrm{gh}^{*}$ & $14.18 \mathrm{ef}^{*}$ & $92.66 \mathrm{de}^{*}$ & $256.9 a-d$ \\
\hline
\end{tabular}


Aly, A. A. et al.

Table (3). Cont.

\begin{tabular}{|c|c|c|c|c|c|c|c|c|c|c|}
\hline \multirow[b]{2}{*}{ No. } & \multicolumn{2}{|c|}{ Treatment } & \multicolumn{8}{|c|}{ Agronomic and technological traits } \\
\hline & Cultivar & Fungicide & $\begin{array}{c}\text { No. of fruiting } \\
\text { branches } / \mathrm{pl}\end{array}$ & $\begin{array}{l}\text { No. of } \\
\text { capsules } \\
\text { Per plant }\end{array}$ & \begin{tabular}{|c|} 
No. of seeds \\
$/$ \\
capsule
\end{tabular} & $\begin{array}{l}1000 \text { seed } \\
\text { weight }(\mathrm{g})\end{array}$ & $\begin{array}{l}\text { Seed yield / } \\
\text { plant (g) }\end{array}$ & $\begin{array}{l}\text { Seed yield / } \\
\text { fed }(\mathbf{k g})\end{array}$ & $\begin{array}{c}\text { Oil } \\
\text { percentage }\end{array}$ & $\begin{array}{l}\text { Oil yield/fed } \\
(\mathrm{kg})\end{array}$ \\
\hline 1 & Giza 9 & Control $^{\mathrm{a}}$ & 9.720 cde & $9.19 \mathrm{e}$ & $7.31 \mathrm{~cd}$ & $5.690 \mathrm{c}-\mathrm{g}$ & $0.446 \mathrm{~cd}$ & $416.6 \mathrm{~cd}$ & $31.03 \mathrm{e}$ & 129.2def \\
\hline 2 & Giza 9 & Bellis $^{D}$ & $10.460 \mathrm{bc}$ & $11.02 \mathrm{~cd}^{*}$ & $8.76 a b^{*}$ & $6.823 \mathrm{ab}^{*}$ & $0.535 a^{*} b^{*}$ & $499.5 b^{*}$ & $37.01 \mathrm{abc}^{*}$ & $184.7 b^{*}$ \\
\hline 3 & Giza 9 & Sulphur ${ }^{c}$ & $11.460 \mathrm{a}^{*}$ & $12.97 \mathrm{a}^{*}$ & $9.12 \mathrm{a}^{*}$ & $7.340 \mathrm{a}^{*}$ & $0.566 \mathrm{a}^{*}$ & $569.3 a^{*}$ & $38.37 \mathrm{a}^{*}$ & $224.8 \mathrm{a}^{*}$ \\
\hline 4 & Giza 10 & Control & $7.850 \mathrm{gh}$ & 8.62 efg & 7.10 & 5.450 efg & 0.408 def & $357.5 \mathrm{~d}-\mathrm{g}$ & $30.28 \mathrm{e}$ & 108.2fgh \\
\hline 5 & Giza 10 & Bellis & $9.413 \mathrm{de}^{*}$ & $10.34 \mathrm{~d}^{*}$ & $8.40 b^{*}$ & $6.533 a-d^{*}$ & $0.489 \mathrm{bc}^{*}$ & $428.7 c^{*}$ & $36.11 a-d^{*}$ & $154.3 \mathrm{c}^{\star}$ \\
\hline 6 & Giza 10 & Sulphur & $10.050 \mathrm{~cd}^{*}$ & $12.15 \mathrm{ab}^{*}$ & $8.99 a b^{*}$ & $6.923 \mathrm{ab}^{*}$ & $0.526 \mathrm{ab}^{*}$ & $505.9 b^{*}$ & $37.54 \mathrm{ab}^{*}$ & $189.8 b^{*}$ \\
\hline 7 & Sakha 3 & Control & $8.320 \mathrm{fg}$ & 8.87 ef & $7.32 \mathrm{~cd}$ & $5.120 \mathrm{fgh}$ & 0.348 ghi & 349.0 efg & $29.29 \mathrm{e}$ & 102.2gh \\
\hline 8 & Sakha 3 & Bellis & $9.980 \mathrm{~cd}^{*}$ & $10.64 \mathrm{~cd}^{*}$ & $8.78 \mathrm{ab}^{*}$ & $6.140 \mathrm{~b}-\mathrm{e}^{*}$ & $0.417 \mathrm{de}^{*}$ & $418.5 \mathrm{~cd}^{*}$ & $35.13 \mathrm{bcd}^{*}$ & $148.1 \mathrm{~cd}^{*}$ \\
\hline 9 & Sakha 3 & Sulphur & $11.150 \mathrm{ab}^{*}$ & $12.43 \mathrm{a}^{*}$ & $9.16 \mathrm{a}^{*}$ & $6.620 \mathrm{abc}^{*}$ & $0.460 \mathrm{~cd}^{*}$ & $506.6 \mathrm{~b}^{\star}$ & $37.32 a b^{*}$ & $189.0 b^{\star}$ \\
\hline 10 & Sakha 4 & Control & 7.520 ghi & $7.86 \mathrm{gh}$ & 7.05 & $4.750 \mathrm{gh}$ & $0.321 \mathrm{hi}$ & $326.2 \mathrm{efg}$ & $29.08 \mathrm{e}$ & $94.75 \mathrm{~h}$ \\
\hline 11 & Sakha 4 & Bellis & $9.020 \mathrm{ef}^{*}$ & $9.43 \mathrm{e}^{*}$ & $8.45 b^{*}$ & $5.700 \mathrm{c}-\mathrm{g}$ & $0.385 \mathrm{efg}^{*}$ & $391.2 \mathrm{cde}$ & $34.87 \mathrm{bcd}^{*}$ & $136.3 \mathrm{cde}^{*}$ \\
\hline 12 & Sakha 4 & Sulphur & $10.010 \mathrm{~cd}^{*}$ & $11.46 b^{*}$ & $8.75 a^{*}$ & $6.520 a-d^{*}$ & $0.441 \mathrm{cde}^{*}$ & $425.4 c^{*}$ & $36.25 \mathrm{a}-\mathrm{d}^{*}$ & $154.5 c^{*}$ \\
\hline 13 & Istro & Control & 6.140 j & $6.61 \mathrm{i}$ & $6.70 \mathrm{de}$ & $4.370 \mathrm{~h}$ & $0.252 \mathrm{jk}$ & $258.4 \mathrm{~h}$ & $28.51 \mathrm{e}$ & $73.0 \mathrm{i}$ \\
\hline 14 & Istro & \begin{tabular}{|l|} 
Bellis \\
\end{tabular} & $7.360 \mathrm{hi}^{\star}$ & $7.92 \mathrm{fgh}^{\star}$ & 6.84 & $5.640 \mathrm{~d}-\mathrm{g}^{\star}$ & 0.302 hij & $309.9 \mathrm{fgh}$ & $33.99 \mathrm{~d}^{*}$ & $104.4 \mathrm{gh}^{\star}$ \\
\hline 15 & Istro & Sulphur & $8.130 \mathrm{gh}^{*}$ & 8.61 efg $^{*}$ & $7.50 \mathrm{c}^{*}$ & $5.750 c-f^{*}$ & $0.357 \mathrm{fgh}^{*}$ & $371.7 \mathrm{c}-\mathrm{f}^{\star}$ & $35.65 a-d^{*}$ & $131.9 \mathrm{cde}^{*}$ \\
\hline 16 & Jiteka & Control & $5.070 \mathrm{k}$ & 5.29 j & $5.18 \mathrm{f}$ & $4.270 \mathrm{~h}$ & $0.218 \mathrm{k}$ & $253.3 \mathrm{~h}$ & $28.38 \mathrm{e}$ & $72.37 i$ \\
\hline 17 & Jiteka & Bellis & $6.080 \mathrm{j}^{*}$ & $6.34 \mathrm{i}^{*}$ & $6.21 \mathrm{e}^{*}$ & $5.400 \mathrm{efg}^{*}$ & $0.261 \mathrm{jk}$ & $303.8 \mathrm{gh}$ & $33.63 \mathrm{~d}^{*}$ & $100.8 \mathrm{gh}^{*}$ \\
\hline 18 & Jiteka & Sulphur & $6.780 \mathrm{ij}^{*}$ & 7.02 hi $^{*}$ & $6.83 \mathrm{de}^{*}$ & $5.650 \mathrm{~d}-\mathrm{g}^{*}$ & $0.296 \mathrm{ij}^{*}$ & $357.6 \mathrm{~d}-\mathrm{g}^{*}$ & $34.11 \mathrm{~cd}^{*}$ & 121.3 efg $^{*}$ \\
\hline
\end{tabular}
Plants were sprayed with water

Bellis was applied as foliar spray at a rate of $50 \mathrm{ml} / 100$ liters of water.

${ }^{c}$ Sulphur was applied as foliar spray at a rate of $250 \mathrm{~g} / 100$ liters of water.

In columns, means followed by the same letter(s) are not significantly $(P<0.05)$ different according to Duncan's multiple range test.

Significant difference from the respective control. 
Table (4). Effect of flax cultivars and fungicides on powdery mildew severity, agronomic, and technological traits under field conditions in 2011/2012 growing season.

\begin{tabular}{|c|c|c|c|c|c|c|c|c|c|c|c|}
\hline \multirow[b]{2}{*}{ No. } & \multicolumn{2}{|c|}{ Treatment } & \multirow[b]{2}{*}{$\begin{array}{c}\text { Disease } \\
\text { severity }(\%)^{d}\end{array}$} & \multicolumn{8}{|c|}{ Agronomic and technological traits } \\
\hline & Cultivar & Fungicide & & $\begin{array}{l}\text { Total plant } \\
\text { length }(\mathbf{c m})\end{array}$ & \begin{tabular}{|c|} 
Technical \\
plant length \\
(cm)
\end{tabular} & $\begin{array}{c}\text { Straw } \\
\text { yield/plant } \\
\text { (g) }\end{array}$ & $\begin{array}{c}\text { Straw } \\
\text { yield/fed. } \\
\text { (ton) }\end{array}$ & $\begin{array}{c}\text { Fiber } \\
\text { yield/fed } \\
\text { (ton) }\end{array}$ & $\begin{array}{c}\text { Fiber } \\
\text { percentage }\end{array}$ & $\begin{array}{c}\text { Fiber } \\
\text { length }(\mathrm{cm})\end{array}$ & $\begin{array}{c}\text { Fiber } \\
\text { fineness } \\
(\mathrm{Nm})\end{array}$ \\
\hline 1 & Giza 9 & & $100.00 \mathrm{a}$ & 9.75 efa & $80.70 \mathrm{fgh}$ & $0.939 \mathrm{cde}$ & $3.569 \mathrm{~cd}$ & $0.5047 \mathrm{fg}$ & $14.12 \mathrm{~cd}$ & $83.83 \mathrm{fa}$ & $233.9 \mathrm{cde}$ \\
\hline 2 & Giza 9 & Bellis $^{b}$ & $43.23 \mathrm{de}^{*}$ & $107.60 a^{*}{ }^{*}$ & $96.76 \mathrm{ab}^{*}$ & $1.126 \mathrm{abc}$ & $4.279 \mathrm{~b}^{*}$ & $0.7240 \mathrm{~cd}^{*}$ & $16.93 \mathrm{~b}^{*}$ & $00.50 b^{*}$ & $276.5 \mathrm{abc}$ \\
\hline 3 & Giza 9 & Sulphur ${ }^{\mathrm{C}}$ & $29.25 \mathrm{~h}^{*}$ & $112.10 a^{*}$ & $100.30 \mathrm{a}^{*}$ & $1.325 \mathrm{a}^{*}$ & $5.015 \mathrm{a}^{*}$ & $0.9290 \mathrm{a}^{*}$ & $18.55 \mathrm{a}^{*}$ & $107.5 \mathrm{a}^{*}$ & $290.6 \mathrm{a}^{*}$ \\
\hline 4 & Giza 10 & & $3.03 \mathrm{c}$ & 3.08 efg & & 0.796 def & $3.488 \mathrm{cde}$ & & 12.87 def & 77.80 hij & \\
\hline 5 & Giza 10 & & & $2 \mathrm{~cd}^{*}$ & $\mathrm{bcd}^{*}$ & $54 \mathrm{cde}$ & & & $3 c^{*}$ & $8 \mathrm{~cd}^{*}$ & \\
\hline 6 & Giza 10 & & $\mathrm{gh}^{*}$ & $105.1 \mathrm{abc}^{\star}$ & & $85 a^{*}$ & & & $5 b^{*}$ & $100.20 b^{\star}$ & \\
\hline 7 & Sakha 3 & & & $2 \mathrm{fg}$ & & & & & 9 def & & \\
\hline 8 & Sakha 3 & & & & & & & & $5 c^{*}$ & & 252 \\
\hline 9 & Sakha 3 & & $\mathrm{~h}^{*}$ & $a b^{*}$ & & $5 \mathrm{bcd}$ & & & $3 a b^{*}$ & $3 \mathrm{bc}^{*}$ & 271. \\
\hline 10 & Sakha 4 & Control & & $3 \mathrm{gh}$ & ghi & $46 \mathrm{fg}^{*}$ & & & $7 \mathrm{gh}$ & $92 \mathrm{jk}$ & $215.3 \mathrm{e}$ \\
\hline 11 & Sakha 4 & & & & & $74 \mathrm{ef}^{*}$ & & & $\mathrm{de}^{*}$ & $e^{*}$ & 244 \\
\hline 12 & Sakha 4 & & & & & $0.948 \mathrm{cde}^{\star}$ & & & $5 c^{*}$ & $\mathrm{~cd}^{*}$ & 265. \\
\hline 13 & Istro & Control & $5 \mathrm{~b}$ & gh & & $70 \mathrm{fg}$ & & & $8 \mathrm{~h}$ & $35 \mathrm{k}$ & 213 \\
\hline 14 & Istro & Bellis & $2 i^{*}$ & $9 \mathrm{de}^{*}$ & $d-g^{*}$ & 83 efg & 3.18 & & 12.45 efg $^{*}$ & $5 \mathrm{fgh}^{*}$ & cde \\
\hline 15 & Istro & & & & & & & & $14.78 c^{*}$ & $5 \mathrm{de}^{*}$ & 261.3 \\
\hline 16 & Jiteka & & & & & & & & & $67.74 \mathrm{k}$ & \\
\hline 17 & Jiteka & Bellis & $44.93 \mathrm{~d}^{*}$ & 92.87 def $^{*}$ & $83.17 \mathrm{~d}-\mathrm{g}^{*}$ & $0.586 \mathrm{fg}$ & $2.829 \mathrm{fgh}$ & $0.3370 \mathrm{ij}^{*}$ & $11.88 \mathrm{fg}^{*}$ & 81.22 ghi* $^{*}$ & $236.4 \mathrm{cde}$ \\
\hline 18 & Jiteka & Sulphur & $36.50 \mathrm{fg}^{*}$ & $98.21 \mathrm{~cd}^{*}$ & $86.30 c-f^{*}$ & $0.755 \mathrm{efg}$ & $3.625 \mathrm{~cd}^{*}$ & $0.4817 \mathrm{gh}^{*}$ & $13.28 \mathrm{de}^{*}$ & 88.50 def $^{*}$ & $255.2 \mathrm{a}-\mathrm{e}$ \\
\hline
\end{tabular}


Aly, A. A. et al.

Table (4). Cont.

\begin{tabular}{|c|c|c|c|c|c|c|c|c|c|c|}
\hline \multirow[b]{2}{*}{ No. } & \multicolumn{2}{|c|}{ Treatment } & \multicolumn{8}{|c|}{ Agronomic and technological traits } \\
\hline & Cultivar & Fungicide & $\begin{array}{l}\text { No. of fruiting } \\
\text { branches/pl }\end{array}$ & $\begin{array}{c}\text { No. of } \\
\text { capsules } \\
\text { Per plant }\end{array}$ & $\begin{array}{l}\text { No. of } \\
\text { seeds / } \\
\text { capsule }\end{array}$ & $\begin{array}{l}1000 \text { seed } \\
\text { weight }(\mathrm{g})\end{array}$ & $\begin{array}{l}\text { Seed yield } \\
/ \text { plant (g) }\end{array}$ & $\begin{array}{c}\text { Seed } \\
\text { yield / fed } \\
(\mathbf{k g})\end{array}$ & Oil percentage & $\begin{array}{l}\text { Oil yield/fed } \\
(\mathbf{k g})\end{array}$ \\
\hline 1 & Giza 9 & Control ${ }^{a}$ & 8.94 def & $9.06 \mathrm{bc}$ & $7.14 \mathrm{bc}$ & $5.573 \mathrm{~d}-\mathrm{g}$ & $0.438 \mathrm{~cd}$ & $385.5 \mathrm{cde}$ & $30.07 \mathrm{~d}$ & 115.8 efg \\
\hline 2 & Giza 9 & Bellis $^{\mathrm{b}}$ & $10.12 \mathrm{abc}^{*}$ & $10.86 a^{*}$ & $8.56 \mathrm{a}^{*}$ & $6.690 \mathrm{ab}^{*}$ & $0.525 \mathrm{ab}^{*}$ & $462.2 a^{*}$ & $35.86 \mathrm{abc}^{*}$ & $143.5 \mathrm{bcd}^{*}$ \\
\hline 3 & Giza 9 & Sulphur ${ }^{\mathrm{C}}$ & $11.00 \mathrm{a}^{*}$ & $11.25 \mathrm{a}^{*}$ & 8.92 & $7.250 \mathrm{a}^{*}$ & $0.548 \mathrm{a}^{*}$ & $518.3 \mathrm{a}^{*}$ & $37.12 \mathrm{a}^{*}$ & $195.7 \mathrm{a}^{*}$ \\
\hline 4 & Giza 10 & Control & $7.69 \mathrm{gh}$ & 7.96 def & 6.82 & 5.300 e-h & 0.386 def & $302.6 \mathrm{fgh}$ & $29.56 \mathrm{~d}$ & 89.29 hij \\
\hline 5 & Giza 10 & Bellis & $9.22 \mathrm{cde}^{*}$ & $9.55 \mathrm{~b}^{*}$ & $8.18 a^{*}$ & $6.350 a-d^{*}$ & $0.463 \mathrm{bcd}$ & 362.8 def & $35.25 \mathrm{abc}^{*}$ & $128.2 \mathrm{cde}^{*}$ \\
\hline 6 & Giza 10 & Sulphur & 9.85 & $10.98 a^{*}$ & 8.64 & $6.627 a b^{*}$ & $0.508 a b c^{\star}$ & ${ }^{*} 428.5 b c^{*}$ & $36.96 a b^{*}$ & $157.2 b^{*}$ \\
\hline 7 & Sakha 3 & Control & 8.69 & 7.66 def & 7.19 & $4.890 \mathrm{f}-\mathrm{i}$ & $0.344 \mathrm{efg}$ & $277.4 \mathrm{ghi}$ & $29.98 \mathrm{~d}$ & $83.05 \mathrm{hij}$ \\
\hline 8 & Sakha 3 & Bellis & 9.22 cde & $9.18 b^{*}$ & 8.62 & $5.860 \mathrm{~d}-\mathrm{e}^{*}$ & 0.412 de & $332.6 \mathrm{efg}$ & $35.75 \mathrm{abc}^{*}$ & 118.9 def $^{*}$ \\
\hline 9 & Sakha 3 & Sulphur & $10.66 a b^{*}$ & $10.62 a^{*}$ & $8.95 \mathrm{a}^{*}$ & $6.520 \mathrm{abc}^{*}$ & $0.452 \mathrm{bcd}^{\star}$ & ${ }^{\star} 388.4 \mathrm{cde}^{\star}$ & $36.66 a b^{\star}$ & $142.5 \mathrm{bcd}^{*}$ \\
\hline 10 & Sakha 4 & Control & 6.78 hij & 7.14 ef & 6.89 & 00 ghi & $0.296 \mathrm{ghi}$ & $281.0 \mathrm{ghi}$ & $29.16 d$ & $81.95 \mathrm{hij}$ \\
\hline 11 & Sakha 4 & Bellis & 8.13 & $8.56 \mathrm{bcd}^{*}$ & 8.26 & $5.640 c-f^{*}$ & 0.355 efg & 336.9 efg & $34.76 \mathrm{abc}^{*}$ & $117.0 \mathrm{efg}^{*}$ \\
\hline 12 & Sakha 4 & Sulphur & 9.55 cde & $10.54 a^{*}$ & 8.65 & $6.460 \mathrm{abc}^{*}$ & $0.422 \mathrm{de}^{*}$ & $416.3 b^{b} d^{*}$ & $35.15 \mathrm{abc}^{*}$ & $149.2 b^{*}$ \\
\hline 13 & Istro & Control & $5.740 \mathrm{jk}$ & $5.99 \mathrm{gh}$ & 5.61 & $4.630 \mathrm{hi}$ & $0.240 \mathrm{ij}$ & $229.6 i$ & $28.14 \mathrm{~d}$ & $64.85 \mathrm{j}$ \\
\hline 14 & Istro & Bellis & 6.88 hi $^{*}$ & $7.18 \mathrm{ef}^{*}$ & 6.73 & 5.350 e-h & $0.288 \mathrm{~g}-\mathrm{j}$ & 275.3 ghi & $33.54 \mathrm{c}^{*}$ & 92.37 ghi $^{*}$ \\
\hline 15 & Istro & Sulphur & $\begin{array}{ll}7.96 \mathrm{fg}^{*}\end{array}$ & $8.14 \mathrm{cde}^{*}$ & 7.18 & $5.560 \mathrm{dg}^{*}$ & $0.326 \mathrm{fgh}^{\star}$ & $348.6 \mathrm{ef}^{*}$ & $34.77 \mathrm{abc}^{*}$ & 121.5 def $^{*}$ \\
\hline 16 & Jiteka & Control & $4.85 \mathrm{k}$ & $5.12 \mathrm{~h}$ & $4.94 \mathrm{e}$ & $4.190 \mathrm{i}$ & $0.207 \mathrm{j}$ & $247.3 \mathrm{hi}$ & $27.75 d$ & 68.67 ij \\
\hline 17 & Jiteka & Bellis & $5.82 \quad \mathrm{ijk}$ & $6.14 \mathrm{q}^{*}$ & 5.92 cde & & $0.248 \mathrm{hij}$ & $296.5 \mathrm{fgh}$ & $32.88 c^{*}$ & $97.64 \mathrm{fgh}^{*}$ \\
\hline 18 & Jiteka & Sulphur & $6.42 \mathrm{ij}^{*}$ & $6.95 \mathrm{fg}^{*}$ & 6.74 & $5.370 \mathrm{f}-\mathrm{h}^{\star}$ & $0.275 \mathrm{~g}-\mathrm{j}$ & $316.9 \mathrm{fg}^{*}$ & $33.74 \mathrm{bc}^{*}$ & $107.20 \mathrm{e}-\mathrm{h}^{*}$ \\
\hline
\end{tabular}

$\begin{array}{ll}18 & \text { Jiteka } \\ \text { Plants were sprayed with water }\end{array}$

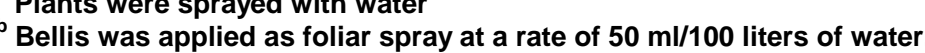

${ }^{c}$ Sulphur was applied as foliar spray at a rate of $250 \mathrm{~g} / 100$ liters of water.

In columns, means followed by the same letter(s) are not significantly $(P<0.05)$ different according to Duncan's multiple range test.

Significant difference from the respective control. 
J. Plant Prot. and Path., Mansoura Univ., Vol. 4 (6): 591 - 601, 2013 